\title{
PENGARUH AKUPRESUR TERHADAP PENURUNAN NYERI DYSMENORHEA
}

\author{
Diyah Tepi Rahmawati ${ }^{1}$,Ronalen Br. Situmorang ${ }^{2}$, Syami Yulianti ${ }^{3}$ \\ Universitas Dehasen Bengkulu Fakultas Ilmu Kesehatan
}

\begin{abstract}
Background: Dysmenorrhea or menstrual pain is pain experienced by women of childbearing age due to the hormone prostaglandin which makes the uterus contract. Acupressure is known as one of the traditional Chinese therapeutic methods for healing dysmenorrhea by using finger massage techniques at the meridian points of certain body parts (acupuncture points). The purpose of this study was to determine the effect of acupressure in adolescent girls with complaints of menstrual pain or dysmenorrhoea. Methods: The method in this study is a quantitative bivariate with the type of research with the Quasy approach of pre-post one group design experiments, data analysis using $T$ Pair test. Samples of 30 female teenagers were obtained by using purposive sampling technique. Result:. Empirically proven acupressure $100 \%$ can be an alternative nonpharmacological therapy that is able to overcome or minimize pain, a statistical test $p$ value <0.001 which means that there is an effect of acupressure on decreasing dysmenorrhea pain in adolescent girls in the city of Bengkulu. With the use of the VAS (Visual Analaog Scale) in this study, the average pain reduction was 2.12. Conclusion: Suggestion. Acupressure is a therapy that is safe, easy, practical and needs to be applied independently and continuously to improve women's reproductive health. But further research is still needed for more valid and relevant results.
\end{abstract}

Keywords: Acupressure, Alternative, Dysmenorrhoea, Adolescents, Therapy

\section{PENDAHULUAN}

Dysmenorhoea atau nyeri haid merupakan nyeri yang terjadi saat menstruasi yang dialami perempuan usia produktif. Produksi prostaglandin yang berlebihan pada endometrial selama fase lutheal merupakan dugaan penyebab dysmenorhea. (Oswati,dkk. 2010) Faktorfaktor penyebab dismenorea menurut Sukini (2012) dalam Sumanto (2015) antara lain hormonal, kelainan organ reproduksi, stres psikis dan malnutrisi. (Sumanto,2015). Nyeri ini biasanya terjadi pada area perut ke bawah. Pada umumnya nyeri ini terjadi pada wanita usia subur yaitu 15-30 tahun. (Novia, 2008).
Menurut Zegeye et al. (2009), Lee et al (2006) dan Chan et al. (2009) dalam Lestari dkk. (2010), persentasi kejadian dismenorea pada remaja putri sekitar 60\%-90\%. (Lestari, dkk. 2010) Nyeri ini dapat mengakibatkan penurunan aktivitas pada tubuh dan kualitas hidup pada perempuan.(El-Gendy,2015, Maryam 2011, Kurniawati,2011).

Gejala-gejala yang ditimbulkan dismenorea antara lain nyeri pada perut, pusing, nyeri pinggang, mual, nyeri punggung dan bahkan dapat menyebabkan pingsan. Penanganan dismenorea sampai saat ini masih berupa terapi farmakologi yaitu pemberian obat analgesik 
(penghilang nyeri) untuk meringankan rasa nyeri haid.

Pada masyarakat Indonesia sendiri, menurut Darmansyah (2006) dalam Rustam (2014), kurang dari 25\% yang melakukan konsultasi dengan dokter untuk masalah dysmenorhea. Dan sebagian besar melakukan pengobatan sendiri karena tindakan tersebut dapat dilakukan segera ketika mengalami nyeri misalnya membeli obat yang dijual bebas.(Rustam,2014)

Riyanto (2002) dalam Novia \& Puspitasari (2008) juga menegaskan bahwa tidak ada angka yang pasti penderita dysmenorhea di Indonesia.

Hal yang sama juga dilaporkan Lestari dkk. Dalam menangani dismenorea, pada sebagian besar masyarakat Indonesia melakukan terapi tradisional yaitu minum air hangat atau melakukan kompres hangat pada bagian tubuh yang sakit.(Lestari,dkk.2010)

Penanganan yang masih sebatas pemberian obat penghilang nyeri dalam jangka waktu lama tentu saja memiliki efek samping yang berbahaya bagi kesehatan perempuan. Perlu adanya alternatif penanganan dismenorea nonfarmakologi misalnya akupresur.

Akupresur dikenal sebagai salah satu metode terapi tradisional china untuk penyembuhan dysmenorhea dengan menggunakan teknik memijat pada titik meridian bagian tubuh tertentu. Terapi akupresur dikenal dengan terapi nonfarmakologi. Penelitian-penelitian terkait pengaruh akupresur terhadap dismenorea akan dibahas lebih lanjut dalam artikel ini.

Penelitian terkait pengaruh akupresur terhadap dysmenorhea di Indonesia masih relatif sedikit. Berangkat dari latar belakang diatas, rumusan masalah dalam penelitian ini yaitu bagaimana pengaruh akupresur terhadap penurunan nyeri dysmenorhea?

\section{METODE PENELITIAN}

Penelitian ini menggunakan desain quasy eksperiment dengan pendekatan pretest-postest one group desain. Kelompok pada penelitian ini diukur nyeri dysmenorhea sebelum dan sesudah dilakukan akupresur. Akupresur dilakukan sebanyak 7 kali oleh terapis dan dilanjutkan mandiri oleh remaja puteri sampai haid berikutnya. Populasi dalam penelitian ini yaitu remaja puteri yang memiliki nyeri dysmenorhea di Kota Bengkulu. Peneliti menetapkan sampel dalam penelitian ini sejumlah 33 responden (total sampling). Sampel remaja puteri yang mengalami dysmenorhea di wilayah Kota Bengkulu diperoleh dengan tehnik purposive sampling.

Kriteria inklusi pada penelitian ini adalah remaja puteri yang memiliki dysmenorhea, bersedia menjadi responden dan kriteria eksklusinya adalah remaja puteri yang memiliki riwayat penyakit/komplikasi. Analisis data menggunakan univariat dan bivariat menggunakan $T$ Paired test.

\section{HASIL PENELITIAN}

Tabel 1. Distribusi Rata-Rata Nyeri Dysmenorhea Remaja Puteri Sebelum dan Sesudah Dilakukan Akupresur pada Remaja Puteri di Kota Bengkulu

\begin{tabular}{ccccc}
\hline Nyeri & Mean & (SD) & $\begin{array}{c}\text { SD } \\
\text { Error } \\
\text { Mean }\end{array}$ & $\mathbf{N}(\%)$ \\
& & \multicolumn{4}{c}{$\begin{array}{c}\text { Mear } \\
\text { Pre }\end{array}$} & $4,73(2,11)$ & 2,11 & 0,367 & $33(100)$ \\
Post & $2,61(1,77)$ & 1,77 & 0,298 & \\
\hline
\end{tabular}

Keterangan uji: *) T Paired

Pada tabel 1 dijelaskan hasil penelitian pre test dan post test pada kelompok penelitian. Pada data pre test 
didapatkan rata-rata nyeri $4,73(2,11)$. Setelah dilakukan akupresur didapatkan nilai post test menjadi $2,61(1,77)$.

Tabel 2. Penurunan Nyeri Dysmenorhea Sebelum dan Sesudah Akupresur Pada Remaja Puteri di Kota Bengkulu

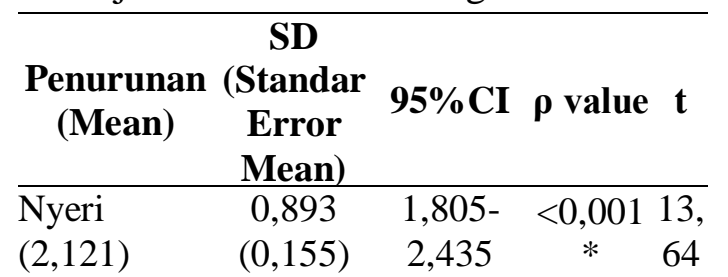

Pada tabel 2 dijelaskan penurunan nyeri rata-rata 2,121. Hasil statistik menunjukkan nilai $\rho$ value $<0,001$, $\mathrm{t}=13,646$ yang berarti bahwa ada perbedaan yang signifikan antara sebelum dan setelah penelitian (dilakukan akupresur).

\section{PEMBAHASAN}

Dysmenorhea adalah penyakit bulanan yang membutuhkan perhatian. Dysmenorhea merupakan nyeri yang biasanya dialami oleh wanita usia subur selama periode menstruasi. Menurut Widjanarko (2006) dalam Novia dan Puspitasari, gejala yang dirasakan oleh penderita yaitu rasa nyeri perut bagian bawah atau panggul, yang menjalar ke punggung dan paha dan terjadi sebelum dan selama menstruasi.(Novia,2008)

Dampak yang ditimbulkan oleh dismenorea misalnya mual, bad mood, dan stress serta dapat menurunkan kualitas hidup dan produktivitas wanita dalam bekerja. (Novia,2008,El Gendy,2015)

Penanganan dysmenorhea masih sebatas pada terapi farmakologi seperti pemberian obat penghilang nyeri. Penelitian yang dilakukan oleh Zafari et al. mengenai perbandingan efektivitas akupresur, kapsul minyak ikan dan ibu profen terhadap dysmenorhea menyimpulkan bahwa akupresur dan kapsul minyak ikan dapat digunakan sebagai pengganti obat penghilang nyeri yang tentu saja banyak memiliki efek samping.(Zafari,2011).

Akupresur dikenal sebagai metode pengobatan cina tradisional. Berbeda dengan akupuntur yang menggunakan jarum sebagai media pengobatan, akupresur menggunakan pijatan jari pada titik-titik meridian untuk memperlancar proses peredaran darah pada tubuh pasien.(Wong,2009.)

Titik-titik akupresur pada dasarnya sama dengan titik-titik pada akupuntur. Untuk melakukan akupresur, pasien hanya membutuhkan informasi mengenai titiktitik meridian yang berhubungan dengan organ internal tubuh pada manusia.(Wong,2009).

Khusus dysmenorhea, titik Sanyinjiao (SP6) adalah titik-titik meridian untuk melakukan akupresur pada penderita dysmenorrhea.

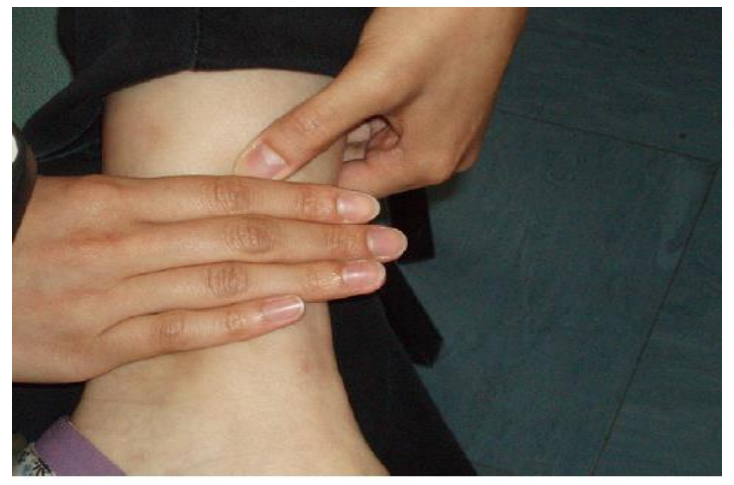

Gambar 1. Titik SP6

Titik Sanyinjiao (SP6) adalah titik meridian yang berhubungan dengan organ limpa, hati dan ginjal. Titik ini berada 4 jari diatas mata kaki. Penelitian-penelitian terkait efektifitas SP6 pada dysmenorhea telah dilakukan. Chen \& Chen (2004) 
misalnya, menegaskan bahwa akupresur merupakan bentuk terapi yang efektif dan aman pada dismenorea. Selain itu, akupresur adalah terapi yang mudah dipelaari dan tanpa biaya. (Chen,2004)

Dalam studi yang dilakukan Habek dan Mehmet (2007), Bostani et al. (2010) dan Kidney et al. (2001), akupresur dapat mengurangi rasa nyeri pada penderita dismenorea dan efektif.

Hal yang sama juga dilaporkan oleh Wong, Lai dan Tse (2009) dalam penelitian mengenai dampak akupresur Sanyinjiao (SP6). Hasil penelitian tersebut menyimpulkan bahwa responden yang mendapat terapi akupresur SP6 dapat meringankan dysmenorea selama kurang lebih tiga bulan.(Wong,2009)

\section{KESIMPULAN DAN SARAN}

Pada penelitian ini telah terbukti bahwa akupresur efektif terhadap penurunan nyeri dysmenorhea. Selain itu, akupresur juga merupakan terapi yang mudah dipelajari (praktis), aman dan tanpa biaya serta perlu dilakukan secara mandiri dan berkesinambungan untuk meningkatkan kesehatan reproduksi perempuan.

Penelitian mengenai pengaruh akupresur SP6 terhadap dysmenorea dysmenorhea di Indonesia masih terbatas sehingga perlu dilakukan penelitian lanjutan dan lainnya untuk hasil yang lebih valid dan relevan.

\section{DAFTAR RUJUKAN}

Oswati Hasanah, Krisna Yetti \& Dessie Wanda. 2010. Eefektivitas Terapi Akupresur Terhadap Intensitas Nyeri Dysmenorea Pada Remaja.

Sumanto. 2015. Penurunan Nyeri Dysmenorea Menggunakan Titik
Akupuntur Guanyuan (Ren 4), Guilai (ST29) dan Sanyinjiao (SP6) Pada Mahasiswa Poltekkes Surakarta. Jurnal Terpadu Ilmu Kesehatan.;Vol. 4 No. 1:64-7.

Novia, Ika \& Nunik Puspitasari. 2008.

Faktor Risiko Yang

Mempengaruhi Kejadian

Dysmenorea Primer. The

Indonesian Journal of Public Health.;Vol.4

Lestari, Hesti, Jane Metusala \& Diana Yuliani Suryanto. 2010. Gambaran Dysmenorea pada Remaja Putri. Sekolah Menengah Pertama di Manado. Sari Pediatri.;Vol.12 No.2:9910No.2:96-104.

El-Gendy, Salwa Roushdy. 2015. Impact of Acupressure on Dysmenorrheal Pain among Teen-aged Girls Students. Wulfenia Journal.;Vol.22 No.2:218-25.

Maryam Kabirian, Zahra Abedian, Seyed Reza Mazlom \& Behroz Mahram. 2011. Self Management in Primary Dysmenorrhea: Toward Evidence-based Education. Life Science Journal.;Vol. 8 No.2:13-8.

Kurniawati, Dewi \& Yuli Kusumawati. 2011. Pengaruh Dismenore Terhadap Aktivitas pada Siswi SMK. Journal Kesehatan Masyarakat;Vol.6 No. 2:93-9.

Rustam, Erlina. 2014. Gambaran Pengetahuan Remaja Puteri 
Terhadap Hyeri Haid

(Dismenore) dan Cara

Penanggulanganny. Journal

Kesehatan Andalas; Vol.3

No.1:286-90.

Zafari, M., M.Tofighi, Aghamohammady A., Behmanesh, F., \& Rakhshaee Z. 2011. Comparison of The Effect of Acupressure, Fish Oil Capsules and Ibuprofen on Treatment of Primary Dysmenorrhoeal. African Journal of Pharmacy and Pharmacology; Vol. 5 No. 8:11159.

C.,Elakkiya.2015. An Experimental Study to Assess The Effectiveness of Acupressure on Dysmenorrhea

Among Adolescent Girls in Hilton Matriculation Higher Secondary School at Chrompet, Chennai. International Journal of Innovative Research \& Development ; Vol. 4(Issue 1):8-10

Wong, C.L., K.Y. Lai \& H.M. Tse.2009. Effect of SP6 Acupressure on Pain and Menstrual Distress in Young Women with Dysmenorrhoea. Complementary Therapies in Clinical Practice ;Vol. 16:64-9.

Chen, Huei-Mein \& Chung-Hey Chen. 2004. Effect of Acupressure at The Sanyinjiao Point on Primary Dysmenhoea. Journal of Advanced Nursing ; Vol.48 No.4:380-7. 